\title{
THE ASSOCIATION BETWEEN KNOWLEDGE, ATTITUDES, AND SMOKING HABIT WITH RELATING FACTORS IN A JUNIOR HIGH SCHOOL
}

\author{
HUBUNGAN ANTARA PENGETAHUAN, SIKAP, DAN \\ PERILAKU MEROKOK DENGAN FAKTOR-FAKTOR \\ YANG MEMENGARUHI PADA SISWA SMP
}

\author{
Dwi Jani ${ }^{1}$, Denish Gunawan ${ }^{2}$, Nawanto A. Prastowo ${ }^{2 *}$ \\ ${ }^{1}$ Medical Education Unit, Faculty of Medicine, Unika Atma Jaya, Jakarta \\ ${ }^{2}$ Department of Physiology, Faculty of Medicine, Unika Atma Jaya, Jakarta \\ *email: nawanto.agung@atmajaya.ac.id
}

\begin{abstract}
Smoking habit in adolescents has been increasing recently. Some factors are associated with the smoking habit. However, there are lacks of information regarding influencing factors to smoking habit in the adolescent. The study aimed to examine how knowledge, attitudes, practice, and other factors play a role in adolescents' smoking. There were 381 female and male students of a junior high school in Jakarta who participated. Influencing factors were knowledge, attitudes, practice, social influence, anti-smoking campaigns. The association between factors was analyzed using appropriate statistical tests. Most students had better knowledge, attitude, and practice. Only two students smoked cigarettes (0.5\%). Gender was significantly associated with knowledge ( $p=0.048)$, social influence $(p=0.000)$, an anti-smoking campaign $(p=0.024)$. Knowledge had an association with social influence $(p=0.002)$ and anti-smoking campaign $(p=0.000)$, whereas attitudes with practice smoking $(p=0.005)$ and anti-smoking campaign $(p=0.000)$. Social influence was also associated with the anti-smoking campaign $(p=0.000)$. In conclusion, students of Permai junior high school had good knowledge, attitudes, and practice of smoking. There are associations between factors that contribute to smoking habit in adolescents.
\end{abstract}

Keywords cigarettes, nicotine, adolescents, health problems, mortality

\begin{abstract}
Abstrak
Jumlah perokok remaja sangat meningkat. Kebiasaan merokok dipengaruhi oleh beberapa faktor. Namun demikian, belum banyak diketahui faktor-faktor yang memengaruhi kebiasaan merokok pada remaja. Tujuan penelitian ini adalah untuk mengetahui pengetahuan, sikap, dan perilaku merokok dan faktor-faktor yang memengaruhi pada remaja. Sebanyak 381 siswa dari satu SMP di Jakarta mengikutyi penelitian. Disamping pengetahuan, sikap, dan perilaku, terdapat faktor lain pengaruh sosial dan kampanye anti rokok. Sebagian besar siswa memiliki pengetahuan, sikap, dan perilaku yang baik terhadap merokok. Hanya 2 siswa yang merokok $(0.5 \%)$. Terdapat hubungan antara jenis kelamin dan pengetahuan $(\mathrm{p}=0.048)$, pengaruh sosial $(\mathrm{p}=0.000)$, dan kampanye anti rokok $(\mathrm{p}=0.024)$. Pengetahuan berhubungan dengan pengaruh sosial $(\mathrm{p}=0.002)$ dan kampanye anti rokok $(\mathrm{p}=0.000)$, sedangkan sikap merokok berhubungan dengan perilaku merokok $(\mathrm{p}=0.005)$ dan kampanye anti rokok $(\mathrm{p}=0.000)$. Pengaruh sosial juga berhubungan dengan kampanye anti rokok $(\mathrm{p}=0.000)$. Sebagai kesimpulan, siswa SMP Permai di Jakarta memiliki pengetahuan, sikap, dan perilaku yang baik terhadap merokok. Terdapat hubungan antara faktor-faktor berpengaruh terhadap kebisaan merokok pada remaja.
\end{abstract}

Kata kunci: Kebiasaan merokok, siswa SMP, faktor-faktor yang memengaruhi.

\section{INTRODUCTION}

Cigarettes have become an essential and significant health problem for smokers and those exposed to inhaling cigarette smoke (passive smokers). Smoking causes numerous diseases and health problems, which affects almost all organ systems. Chronic lung diseases such as chronic bronchitis and emphysema, heart 
disease, fetal disorders and pregnancy, fertility and impotence disorders, malignant diseases such as lung cancer, mouth cancer, pharynx cancer, and nasal cavity cancer, are often associated with smoking. Infants and young children exposed to cigarettes are having a higher risk of Sudden Infant Death Syndrome (SIDS), pneumonia, bronchitis, pneumonia, and tend to develop asthma attacks (U.S.Department of Health and Human Services, 2014; U.S. Department of Health and Human Services, 2010; Centers for Disease Control and Prevention, 2013; Pirie, et al., 2013; U.S. Department of Health and Human Services, 2010; Jha, et al., 2013).

Smoking affects mortality and life expectancy. Mortality in smokers is reported to be higher, while life expectancy is lower than non-smokers. Based on data from the World Health Organization (WHO), it is estimated at approximately 8 million deaths from smoking per year. As many as 7 million deaths due to direct use of cigarettes (active smokers), while 1 million more deaths due to exposure (passive smokers) (WHO, 2019). Smokers' mortality is three times higher than non-smokers ( U.S.

Department of Health and Human Services, 2014). Also, smokers die younger than nonsmokers. A study demonstrated that smokers die at ten years younger and mortality rates in middle age are higher than non-smokers (Doll, et al., 2004).

Indonesia is a developing country with a high prevalence of smokers. Based on the Global Adult Tobacco Survey (GATS) in 2011, showing that compared to other countries implementing GATS (16 middle-income countries), Indonesia ranked first with the highest prevalence of active smokers $(67.0 \%$ men and women 2.7\%). This prevalence is higher than India $(47.9 \%$ for men and $20.3 \%$ for women), the Philippines (47.7\% for men and $9.0 \%$ for women), Thailand (45.6\% for men and women $3.1 \%$ ), and Vietnam $(47.4 \%$ men and $1.4 \%$ women) (Indonesian Ministry of Health, 2012). In addition to active smokers, the number of passive smokers is also quite high. According to the Indonesian Ministry of Health, exposure to cigarette smoke was found $51.3 \%$ or about 14.6 million adults in workplaces, and $78.4 \%$ or 133.3 million adults at homes. Exposure to cigarette smoke was also experienced by $85.4 \%$ or 44.0 million adults who visited restaurants.
This illustration shows that passive smokers are at high prevalence (Indonesian Ministry of Health, 2012). The trend of smoking habit among adolescents aged 15-19 years in Indonesia also increased. It was estimated adolescents smokers increased by six times from $7.1 \%$ in 1995 to $43.3 \%$ in 2010 (Indonesian Ministry of Health, 2012). According to data from Riskesdas (2013), the smoking habit start at the age of 10-14 years was $9 \%$ and at the age of 15-19 was 50\% (Research and development agency, Indonesian Ministry of Health, 2013).

Smoking habit relate to several factors. However, there are still conflicting results between studies. Alamsyah et al. observed that low knowledge and negative attitudes were associated with smoking habit in adolescents (Alamsyah, et al., 2017).

Nevertheless, Rachmat et al. reported that smoking habit in junior high school were associated with attitudes and social interaction with peer group but not with knowledg (Rchmat, et al., 2013). Thus, this study aimed to determine the association between knowledge, attitudes, and some factors with smoking habit in junior high school students.

\section{RESEARCH METHODS}

This cross-sectional was conducted in SMP Permai 1, 2, dan 3 Pluit from February to April 2017 by involving male and female junior high school students. The Ethical Committee of Unika Atma Jaya, Jakarta, approved the study (Number: 38 / 11 / KEP-FKUAJ / 2016). Assessment of knowledge, attitudes, and behavior with smoking used a questionnaire from the Global Youth Tobacco Survey (GYTS) that has been modified by adding several questions (Warren, et al, 2007). The GYTS questionnaire with core questions was used, but several questions were added. Additional questions were developed to obtain information about knowledge, attitudes, and behavior variables. The prior study has also performed the use of modified GYTS (Al-Bedah and Qureshi, 2011). Participants filled out the questionnaire and additional questions in its original language without translating it into Indonesian due to their reasonably good English. Every question which was answered 'yes' would get a score of 1 and 'no' will get a score of 0 .

Knowledge, attitudes, and behavior were classified. Classification of knowledge was 
'good' if score $>80 \%$, 'fair' if score $60-80 \%$, and 'poor' if score $<60 \%$. Classification of attitudes was 'positive' if participants answered 'agree' or 'strongly agree' more than $50 \%$, and 'negative' if the answer 'disagree' and 'strongly disagree' were more than $50 \%$. Behavior was classified into 'negative' if participants did not smoke and 'positive' if smoked. The influence of the social environment and anti-smoking campaigns were also analyzed.

Included in the social environment were parents, brothers \& sisters, uncle \& auntie, cousins or other kinship and people around subjects who frequently interact, including classmates, schoolmates, school staff and teachers, playmates, and neighbors. Positive if any one of the family smoked. The anti-smoking campaign was all anti-smoking messages or dangerous effects of smoking in the form of multimedia videos, billboard ads, T.V. ads, discussion in seminar or group, article, etc. According to how often participants were exposed, classification was made into frequent if they were exposed once or more times a week, seldom if less than once a week, and none if never exposed within one month.

Numerical data from scores of knowledge, attitudes, and behaviors will be displayed as mean and standard deviation $(x \pm S D)$. The numerical data from the questionnaire will be converted into categorical data according to their classification. Then categorical data will be displayed as number and percentage (\%) of subjects in each category. Chi-Square tests will be applied to compare the level of knowledge, attitudes, and behaviors with influencing factors (gender, social smoking influence, and antismoking campaign). Fisher's exact test would be used as an alternatives test if Chi-square did not meet the requirements. The statistical test was significant when $p<0.05$. Data processing and statistical analysis were computed using SPSS version 15

\section{RESULTS AND DISCUSSION}

Three hundred eighty-one students from grade 1-3 participated in this study. The characteristics of the participants are described in Table 1. Participants' age ranged between 1116 years. According to gender, subjects consist of $204(53.5 \%)$ females and $177(46.5 \%)$ males. Most participants had a fair knowledge of smoking (51.4\%), positive attitudes (380/99.7\%), and negative behavior
(379/99.5\%) about smoking. Two students (all males) admitted to smoke cigarettes.

Table 1. Characteristics of The Participants

\begin{tabular}{ll}
\hline \multicolumn{1}{c}{ Variable } & $\mathbf{x} \pm$ SD or $\mathbf{n}(\%)$ \\
\hline Age & $13.2 \pm 0.95$ \\
Gender & \\
$\quad$ Female & $204(53.5 \%)$ \\
$\quad$ Male & $177(46.5 \%)$ \\
Knowledge of smoking & \\
$\quad$ Poor & $96(25.2 \%)$ \\
$\quad$ Fair & $196(51.4 \%)$ \\
$\quad$ Good & $89(23.4 \%)$ \\
Attitudes to smoking & \\
$\quad$ Positive & $380(99.7 \%)$ \\
$\quad$ Negative & $1(0.3 \%)$ \\
Practice smoking & \\
$\quad$ Positive & $2(0.5 \%)$ \\
$\quad$ Negative & $379(99.5 \%)$ \\
\hline
\end{tabular}

Table 2 describes the distribution of influencing factors according to gender. On knowledge, female students have more subjects with better knowledge (fair and good) than males (147 vs. 138) but with a lower percentage $(72.1 \%$ vs $78 \%)$. There are no negative attitudes in females, whereas there is one student with negative attitudes in male. No one of the female students smoked cigarettes, whereas two male students smoke. Female students have more influence from non-smokers $(90.2 \%)$ compared with males $(57.1 \%)$. Male students have more subjects exposed to anti-smoking frequently than females (106 vs. 94). However, there was a similar number between male $\&$ female students who had no exposure to the anti-smoking campaign $[5(2.8 \%)$ vs. $6(2.9 \%)]$.

The association between influencing factors are shown in Table 3. The table contains a summary of the Chi-Square or Fisher's exact test. Gender was associated with knowledge, social influence, and anti-smoking campaign. Females had better knowledge $(p=0.048)$, more considerable influence from non-smokers $(p=0.000)$, but with less exposure to the antismoking campaign $(p=0.024)$ than male students. Knowledge had an association with social influence and anti-smoking campaigns. Students with better knowledge received more social influence from non-smokers $(p=0.002)$ and anti-smoking campaigns $\quad(p=0.000)$. Attitudes toward smoking are affected by the anti-smoking campaign $(p=0.000)$. Also, attitudes affect practice smoking $(p=0.005)$. Beside attitudes, practice is also affected by the anti-smoking campaign $(p=0.000)$. 
Table 2. Characteristics Different Between Gender

\begin{tabular}{lrrl}
\hline \multicolumn{1}{c}{ Variable } & $\begin{array}{r}\text { Female } \\
(\mathbf{n = 2 0 4})\end{array}$ & $\begin{array}{c}\text { Male } \\
(\mathbf{n = 1 7 7})\end{array}$ & $\begin{array}{c}\text { Total } \\
(\mathbf{n = 3 8 1})\end{array}$ \\
\hline Knowledge & & & \\
$\quad$ Poor & 57 & 39 & $96(25.2 \%)$ \\
$\quad$ Fair & 93 & 103 & $196(51.4 \%)$ \\
$\quad$ Good & 54 & 35 & $89(23,4 \%)$ \\
Attitudes & & & \\
$\quad$ Positive & 204 & 176 & $380(99.7 \%)$ \\
$\quad$ Negative & 0 & 1 & $1(0.3 \%)$ \\
Practice smoking & & & \\
$\quad$ No & 0 & 2 & $2(0.5 \%)$ \\
$\quad$ Yes & 204 & 175 & $379(99.5 \%)$ \\
Social influence & & & \\
$\quad$ Smoker & 20 & 76 & $96(25.2 \%)$ \\
$\quad$ Non-smoker & 184 & 101 & $285(74.8 \%)$ \\
Anti-smoking campaign & & & \\
$\quad$ Frequent & 94 & 106 & $200(52.5 \%)$ \\
$\quad$ Seldom & 104 & 66 & $170(44.6 \%)$ \\
$\quad$ Never & 6 & 5 & $11(2.9 \%)$ \\
\hline
\end{tabular}

Table 3. P-value of The Chi-square Test Between Variables.

\begin{tabular}{lllllll}
\hline \multicolumn{1}{c}{ Variables } & Gender & Knowledge & Attitudes & $\begin{array}{c}\text { Smoking } \\
\text { habit }\end{array}$ & $\begin{array}{c}\text { Social } \\
\text { influence }\end{array}$ & $\begin{array}{c}\text { Anti-smoking } \\
\text { campaign }\end{array}$ \\
\hline Gender & 1.000 & 0.048 & $0.465^{*}$ & $0.215^{*}$ & 0.000 & 0.024 \\
Knowledge & - & 1.000 & 0.226 & 0.051 & 0.002 & 0.000 \\
Attitudes & - & - & 1.000 & 0.005 & $0.252^{*}$ & 0.000 \\
Smoking habit & - & - & - & 1.000 & 0.063 & 0.000 \\
\hline
\end{tabular}

*Fisher's exact test

Smoke cigarettes cause death, and many diseases are affecting all organ systems in humans. Not only the active smoker but also passive smokers will get the consequences. Many studies and surveys on smoking have been conducted but mostly in young and adults. Smoking is reported to overgrow in children and adolescents. This study attempted to perform a survey in adolescents (junior high school students) regarding their knowledge, attitudes, and behavior associated with certain factors on smoking. The results demonstrated that most students had fair and good knowledge. Only one student had negative attitudes, and only two students smoke cigarettes. Smoking habit was related to attitudes and anti-smoking campaign. The attitudes included in this study were attitudes towards parents or friends who smoke, family discussion about smoking, intension to smoke, and their perspectives on smoking people.

Muliyana and Thaha have conducted a study on cigarette smoking in students of the University of Hasanuddin in 2013. They found high rates of smoking habit as many as $24.1 \%$
(Muliyana and Thaha, 2013). There was a few numbers of students smoked cigarettes in our study. Our study found that only $2(0.5 \%)$ students reported smoking habit. Our finding was almost similar to a study by Raina et al., which found that only $1 \%$ of students aged $13-$ 15 years in India had a smoking habit (Raina, et al., 2015). This large discrepancy with Muliyana and Thaha study may associate with age between subjects of the studies in which smoking habit is higher in older age. However, a study the Global Youth Tobacco Survey (GYTS) in Saudi Arabia reported that tobacco use was quite high among students aged 13-15 years (Al-Bedah and Qureshi, 2011). Larger samples (1830) from several schools and male subjects might only cause higher tobacco use than our study. Smoking habit are known to be affected by several factors. Knowledge, attitudes, access to cigarettes, smoking by family and peers, and tobacco advertisement contribute to smoking behavior (Al-Bedah and Qureshi, 2011; Muliyana and Thaha, 2013). Different from previous studies, our study found that smoking habit was related only 
with attitudes but not with other variables. Compared with previous studies, the number of smokers in our study was too small. This probably affected the statistics results. The more significant number of students with good knowledge, the lower influence of smokers in family and people around, and very high exposure to the anti-smoking campaign may cause the smoker in our study was very few. Other studies have performed a study on knowledge, attitudes, and practice of cigarette smoking in adolescents. Raina et al. conducted their study in students aged 13-15 years in India (Raina, et al., 2015). They found that most students had good knowledge(94\%)and attitudes $(92 \%)$. Our findings were a little bit different but mostly had good knowledge and attitudes. There were $74.8 \%$ of students with fair and good knowledge and $99.7 \%$ with positive attitudes.

The hazardous risks of smoking do not fear some people (Asma, et al., 2004; Marshall, et al., 2006). Addictive ingredients contained in cigarettes make smokers neglect all adverse effects. Addiction to smoking is considered as a window to other addiction such as drugs. A massive pro-smoking campaign by manufacturers impresses that smoking is a modern lifestyle, manhood, and bravery (AlBedah and Qureshi, 2011). This is a powerful attraction for adolescents, mainly males. An anti-smoking campaign has been launched to counteract the pro-smoking campaign. This campaign seems to be successful in our subjects. We found an anti-smoking campaign associated with smoking status, and a minimal number of students smoke.

Our study also has a limitation. First, it involved a small sample size from three schools in one sub-district. The sample may not represent most of the students in Jakarta. Larger samples of more schools from more sub-district should be involved. There might be different social statuses, social influence, a personal character that could influence the knowledge, attitudes, and smoking habit.

In conclusion, our findings demonstrate that students of junior high school of SMP Permai 1,2, 3 have good knowledge, attitudes, and smoking habit. There are very few numbers of students who had smoking habit. The smoking habit was associated with attitudes and antismoking campaign.

\section{Acknowledgments}

The authors would like to thank all students, teachers, and principals of SMP Permai, Pluit, Jakarta.

\section{Disclosure}

The authors declare that there is no conflict of interest.

\section{REFERENCES}

1] U.S. Department of Health and Human Services.The Health Consequences of Smoking-50 Years of Progress: A report of the Surgeon General. Atlanta: U.S. Department of Health and Human Services. Centers for Disease Control and Prevention. National Center for Chronic Disease Prevention and Health Promotion. Office on Smoking and Health. 2014.

2] U.S. Department of Health and Human Services. How tobacco smoke causes disease: What it means to you. Atlanta: U.S. Department of Health and Human Services. Centers for Disease Control and Prevention. National Center for Chronic Disease Prevention and Health Promotion. Office on Smoking and Health. 2010.

3] Centers for Disease Control and Prevention. QuickStats: Number of deaths from 10 leading causes-National Vital Statistics System, United States, 2010. MMWR. 2013;62(08):155.

4] Pirie K, Peto R, Reeves GK, Green J, Beral $\mathrm{V}$. The 21 st-century hazards of smoking and benefits of stopping: a prospective study of one million women in the U.K. Lancet 2013; 381(9861):133-41.

5] U.S. Department of Health and Human Services. Women and Smoking: A Report of the Surgeon General. Rockville (M.D.): U.S. Department of Health and Human Services. Public Health Service. Office of the Surgeon General. 2001.

6] Jha $P$, Ramasundarahettige $C$, Landsman V, Rostrom B, Thun M, Anderson RN, McAfee T, Peto R. 21st Century Hazards of Smoking and Benefits of Cessation in the United States. NEJM. 2013; 368(4):34150.

7] World Health Organization. Tobacco. 2019. www.who.int/news-room/factsheets/detail/tobacco. 
8] Doll R, Peto R, Boreham J, Sutherland I. Mortality in relation to smoking: 50 years' observations on male British doctors. BMJ. 2004; 328(7455): 1519.

9] Kementerian Kesehatan Republik Indonesia. Kemenkes Luncurkan Hasil Survei Tembakau. 2012. Available from: http://www.depkes.go.id/article/print/20 48/kemenkes-luncurkan-hasil-surveitembakau.html

10] Kementerian Kesehatan Republik Indonesia. Melindungi Generasi Bangsa dari Iklan, Promosi dan Sponsor Rokok, Menkes Luncurkan Peraturan Pencant. 2013. Available from: http://www.depkes.go.id/article/view/2310/ melindungi-generasi-bangsa-dari-iklanpromosi-dan-sponsor-rokok-menkesluncurkan-peraturan-pencantum.html

11] Badan Penelitian dan Pengembangan Kesehatan Kementerian Kesehatan RI. Riset Kesehatan Dasar 2013. Available from:

http://www.depkes.go.id/resources/downlo ad/general/Hasil\%20 Riskesda s\%202013.pdf

12] Alamsyah A, Nopianto. Determinan perilaku merokok pada remaja. Journal Endurance. 2017; 2(1): 25-30

13] Rachmat M, Thaha RM, Syafar M. Perilaku merokok remaja sekolah menengah pertama. Kesmas. 2013;7(11): 502-508
14] Warren CW, Jones NR, Peruga A, Chauvin J, Baptiste JP, Costa de Silva V, el Awa F, Tsouros A, Rahman K, Fishburn B, Bettcher DW, Asma S, Centers for Disease Control and Prevention (CDC). Global youth tobacco surveillance, 2000-2007. MMWR Surveill Summ. 2008; 57(1):1-28

15] Al-Bedah AM, Qureshi NA. The Global Youth Tobacco Survey: 2001-2002 in Riyadh region, the Kingdom of Saudi Arabia. Subst Abuse Rehabil. 2011; 2: $197-$ 204. doi: 10.2147/SAR.S23626

16] Muliyana D, Thaha ILM. Faktor yang berhubungan dengan tindakan merokok pada mahasiswa Universitas Hasanuddin Makassar. Jurnal Media Kesehatan Masyarakat Indonesia. 2013:9(2):109-19

17] Raina R, Krishna M, Murali R, Shamala A, Yalamalli M, Kumar AV. Knowledge, attitude and behavioral determinants of tobacco use among 13-15 year old school children. J Int Soc Prev Community Dent. 2015; 5(4): 321-6. doi: 10.4103/22310762.161764

18] Asma S, Warren W, Althomsons S, Wisotzky M, Woollery T, Henson R. Addressing the chronic disease burden with tobacco control programs. Public Health Rep. 2004; 119(3):253-62.

19] Marshall L, Schooley M, Ryan H, et al. Youth tobacco surveillance-United States, 2001-2002. MMWR Surveill Summ. 2006; 55(3):1-56. 